\title{
2.5 Форми організації самостійної роботи студентів у другій половині XX століття
}

Спадщина українських педагогів другої половини XX ст. засвідчує використання різноманітних форм організації самостійної роботи студентів у різноманітному їх поєднанні. Науковцями також доведено, що вибір форм самостійної роботи залежить від мети та завдання навчальної діяльності. 3'ясовано, що організації самостійної роботи студентів у вітчизняних університетах другої половини XX століття приділялася значна увага як на аудиторних заняттях, так і в їхній позааудиторній діяльності. Дослідження засвідчило, що у вітчизняних університетах другої половини $\mathrm{XX}$ століття (Донецький, Київський, Харківський, Одеський та ін.) використовували різні форми самостійної роботи студентів: фронтальну (під час проведення лекцій, конференцій та ін.), групову (на семінарах, практичних і лабораторних заняттях, консультаціях, колоквіумах, у роботі наукових студентських гуртків i товариств), індивідуальну (підготовка рефератів, курсових, дипломних проектів тощо).

Аналіз педагогічної літератури досліджуваного періоду засвідчив, що викладачі вищої школи наголошували на необхідності деяких організаційних та методичних змін під час проведення занять. У плані організаційних змін викладачі вітчизняних університетів спрямовували свої зусилля на визначення місця та характеру самостійної роботи студентів на аудиторних заняттях та заохочували студентів до активної діяльності, стимулювали формування позитивної мотивації навчання та установки на засвоєння навчального матеріалу, підготовку молодих людей до сприйняття нового навчального матеріалу, організацію зворотнього зв'язку для 3'ясування ступеня розуміння нової інформації, планування бюджету часу студентів тощо. У методичному плані було переглянуто співвідношення аудиторної та позааудиторної самостійної роботи студентів, лекційних, семінарських, лабораторних та практичних занять, розроблено відповідні рекомендації з організації та керування самостійною роботою студентів [54, с. 2, с. 3]. 
У ході наукового пошуку встановлено, що лекції в університетах другої половини XX ст. вміщували узагальнений матеріал фундаментальних наукових посібників, спеціальних монографій та інформацію з наукових праць, які не були включені до списку обов'язкових джерел. Досвід проведення лекційних занять засвідчив, що у процесі викладання лекції доцільно висвітлювати тільки основні питання 3 дисципліни, забезпечувати концептуально-методологічний або проблемний характер лекції, розкривати логіку основних положень дисципліни та засоби їх використання у майбутній професійній діяльності, а головне - орієнтувати студентів на самостійну роботу [57, с. 24].

Аналіз педагогічної спадщини другої половини XX ст. дозволив виділити різні види лекцій, які відрізнялися ступенем участі студентів у пошуковій пізнавальній діяльності. Зокрема, проводилися лекції, які характеризувалися:

- найменшим ступенем спонукання до самостійності (лекція-монолог);

- невисоким рівнем самостійності, під час яких однак проявляється зацікавленість студентів (бінарна лекція, лекція-інцидент);

- середнім ступенем спонукання до самостійності (лекції-дискусійні бесіди, лекції-консультації);

- високим ступенем самостійності (проблемні лекції, лекції 3 „навмисними” помилками, „мозкова атака”) [58].

Вважаючи головним призначенням лекції грамотне керування пізнавальною діяльністю студентів, педагоги вітчизняних університетів другої половини XX ст. приділяли значну увагу управлінню цією діяльністю, розвитку їхніх пізнавальних інтересів, забезпеченню творчого оволодіння знаннями, формуванню самостійного наукового мислення та світогляду, що сприяло системному керуванню процесом становлення особистості спеціаліста. Педагоги організовували лекції таким чином, щоб у процесі пізнавальної діяльності вони виховували майбутніх спеціалістів, вчили міркувати та робити адекватні висновки, пробуджували у студентів бажання засвоювати нові знання. На підставі цього особливе місце займали проблемні лекції, на яких 
студенти осмислювали сутність певного процесу чи явища та засвоювали матеріал у процесі активної пізнавальної діяльності [58, с. 6, с. 7].

Сутність проблемного викладення лекції викладачі вітчизняних університетів убачали в активізації самостійної роботи майбутніх фахівців. Для цього вони залучали студентів до спільного обговорення та вирішення навчальних питань, підводили молодих людей до самостійних умовиводів. На етапі постановки гіпотез викладачі спрямовували свої зусилля на те, щоб студенти навчилися пропонувати своє бачення проблеми, вчитися доводити свою правоту, відбирати найбільш адекватні варіанти вирішення проблеми. Підтримка зворотнього зв’язку з аудиторією відбувалася за допомогою таких питань до студентів, як: Чим можна пояснити? Як ви аргументуєте? Як довести? Чому? тощо [57].

Досвід роботи педагогів вищої школи другої половини ХХ ст. засвідчив, що проблемні лекції сприяли розвитку самостійності майбутніх спеціалістів, їх активної участі у науковій праці, створювали умови для поглибленої самостійної творчої діяльності студентів. Причому важливо, щоб новий матеріал базувався на отриманих раніше знаннях, а завдання були посильними для студентів. Педагоги наголошували, що саме такий підхід стимулює студентів до активної самостійної роботи не тільки під час проведення лекції, але й на семінарських, лабораторних та практичних заняттях [54, с. 4, с. 6].

Незважаючи на появу окремих цінних доробків у галузі організації самостійної роботи студентів на лекційних заняттях, викладачі констатували, що у більшості випадків такі заняття все ж таки часто мали лише інформативний характер, що було пов'язано 3 неготовністю студентів сприймати велику кількість нового матеріалу. Вивчення передового досвіду засвідчило, що для покращення ситуації деякі педагоги з самого початку навчання студентів у вищому навчальному закладі центральне місце відводили саме самостійній роботі студентів під керівництвом викладача, що дозволяло на лекційних та семінарських заняттях працювати зі студентами, які вже ознайомилися 3 
навчальним матеріалом, визначили незрозумілі для себе моменти та підготували питання до викладачів.

Разом $з$ тим, педагоги університетів другої половини ХХ ст. розуміли, що навіть на проблемних лекціях складно, а інколи взагалі неможливо створити умови для самостійної роботи студентів. Тому значна увага організації самостійної роботи приділялася на семінарських, практичних і лабораторних заняттях. Причому її функції і види змінювалися залежно від дидактичної мети заняття.

У ході дослідження встановлено, що важливу ролі у становленні студентів як майбутніх спеціалістів в університетах другої половини XX ст. відігравали семінарські заняття. Досвід проведення таких занять засвідчив, що за умови грамотної організації такі заняття сприяють розвитку у студентів наукового мислення, поглибленому вивченню дисципліни, вчать вибірково використовувати отримані знання відповідно до навчальної ситуації, прищеплюють студентам активну життєву позицію, самостійність, вміння творчо працювати 3 літературою, аналізувати отримані результати тощо. Кандидат економічних наук В. Нестеренко (Київський державний університет) зазнав, що семінарські заняття дозволяють вирішити навчальні та виховні завдання, здійснити контроль за самостійною роботою студентів, перевірити їі результати, узагальнити та закріпити матеріал, що вивчався [57, с. 6, с. 8].

Як з’ясовано, мету семінару педагоги вітчизняних університетів вбачали у формуванні у студентів власної точки зору на проблему та визначення шляхів іiі вирішення на основі вивченого матеріалу, формуванні самостійного мислення студентів. Досвід проведення семінарських занять засвідчив, що у цьому випадку під час сумісних пошуків студенти засвоюють не готові істини, а майже самостійно відкривають для себе ті чи інші закономірності [57, с. 9].

Аналіз педагогічної літератури та архівних джерел другої половини ХХ ст. дозволив зробити висновок, що у багатьох університетах приділялася велика увага поліпшенню якості проведення семінарів. Традиційно у вітчизняних університетах другої половини ХХ ст. перед проведенням семінару студенти 
самостійно вивчали матеріал з відповідної теми, використовуючи різноманітні джерела інформації, виконували завдання або готували відповіді з наступним колективним обговоренням та оцінюванням результатів самостійної роботи під керівництвом викладача. На таких заняттях під час колективного обговорення матеріалу спостерігалося підвищення самостійності та активності студентів [57, c. 10].

Було виявлено, що в тих випадках, коли викладачі приділяли значну увагу організації самостійної роботи з першоджерелами та обмірковували методику проведення семінарів, заняття проходили цікаво та відрізнялися високою активністю студентів. Як підтверджено досвідом викладачів, семінарські заняття, які проводилися на високому методичному та професійному рівні, озброювали майбутніх фахівців грунтовними теоретичними знаннями та розвивали в них самостійне мислення. Навпаки, формальна організація самостійної роботи під час проведення семінарських занять призводила до виявлення студентами низького рівня знань.

Для підвищення ефективності семінарських занять кафедри проводили різні заходи. Наприклад, для допомоги студентам більшість кафедр Харківського державного університету розробляли плани семінарських занять, в які було включено ключові теоретичні питання та вказані джерела для самостійного опрацювання У цьому ж університеті записували окремі заняття на плівку 3 метою подальшого їх аналізу [64, с. 87].

Як констатували викладачі вітчизняних університетів другої половини XX ст. на семінарських заняттях студенти зазвичай виступали із доповідями за заздалегідь підготовленим питанням або з обговоренням проблемних питань без попередньої підготовки, доповнювали відповіді товаришів, брали участь у дискусіях тощо. На основі своєї практичної роботи викладачі (Г. Аллік, Т. Аллік, Ю. Козирєв) виділили деякі правила щодо підготовки молодими людьми усної доповіді, а саме: виступ із доповіддю має не перевищувати 10-15 хвилин, студенти можуть використовувати свої записи та опорні схеми, але читати їх 3 
листа не дозволялося, перед доповіддю необхідно ознайомити аудиторію із ключовими термінами або поняттями тощо [63, с. 12, с. 13$]$.

Певну цінність для нашого дослідження має досвід роботи таких викладачів, як Г.Гержод та А. Курас, які, намагаючись створити творчу атмосферу на занятті, активізували розумову діяльність студентів шляхом виділення та формулювання основних питань, виявлення проблемних ситуацій. Аналіз проведення семінарських занять дозволив педагогам зробити висновок, що вміло створена та вирішена проблемна ситуація під час семінарських занять дає позитивний ефект: збільшується пізнавальна активність молодих людей, усі студенти беруть участь у вирішенні проблемної ситуації, самостійно здобуті знання швидше запам'ятовуються та міцніше засвоюються. До провідних на семінарських заняттях науковці відносили пошукові та дослідницькі методів навчання, причому вони намагалися забезпечити діалектичну єдність репродуктивної та творчої діяльності студентів [57].

Аналіз наукової та педагогічної літератури досліджуваного періоду дозволив виділити основні види семінарських занять, що проводилися у вітчизняних університетах, а саме:

- семінари-брифінги, семінари-дискусії; семінари-конференції;

- семінари-дослідження;

- проблемні семінари;

- семінари-практикуми;

- семінари-прес-конференції;

- спецсемінари.

Як 3'ясовано, семінари-брифінги (семінари-дискусії; семінариконференції) проводилися з метою залучення студентів до участі в обговоренні навчального матеріалу. Під час їх проведення студенти репрезентували свою точку зору та вчилися самостійно ії відстоювати. Семінари цього типу, як правило, включали питання для інтелектуальної розминки, основою якої була проблемна стаття з теми або порівняння декількох точок зору на матеріал, що вивчався. У процесі навчання викладач спрямовував пізнавальну діяльність 
студентів у потрібному напрямку, допомагав студентам об'єктивно оцінити інформацію [57, с. 6 , с. 14$]$.

Для участі у семінарі-дослідженні студентам також необхідно було провести попередню самостійну роботу: написати реферат, доповідь, тези виступу тощо. Участь у семінарі цього типу передбачала, перш за все, діалог студента, що виконував завдання, 3 викладачем, а потім продовження обговорення зі всією групою. Під час підготовки до участі у семінарідослідженні студенти аналізували результати теоретичних досліджень 3 цього питання, складали план доповіді та бібліографію до неї. У світлі цього цікавим є досвід організації семінарських занять в Одеському державному економічному університеті (у минулому кредитно-економічному інституті). Так, на кафедрі грошового обігу для активізації семінарських занять та самостійної роботи студентів широко застосовувалося реферування проблемних статей зі спеціальних журналів, рецензій та монографій із навчальної теми. У процесі своєї педагогічної діяльності Ю. Козирєв переконався, що такий метод роботи змушує ретельно ознайомитися 3 питаннями та виключає зубріння студентами матеріалу [66].

Проблемний семінар вимагав від викладача грунтовної підготовки до його проведення, урахування традиційних та нетрадиційних підходів до вирішення проблеми, добору проблемних та контрольних питань до нього. Від студентів підготовка до таких семінарів вимагала ретельної самостійної праці не тільки 3 підручниками та конспектами, але й іншими джерелами інформації: довідниками, науковими статтями, журналами тощо.

Семінари-практикуми у вітчизняних університетах другої половини ХХ ст. проводилися, як правило, студентами старших курсів після консультації 3 викладачем, що стимулювало в них творчу активність. Досвід засвідчив, що студенти охоче обирали в групі ведучого. Після цього організовувалося активне обговорення навчального матеріалу, що сприяло закріпленню їх професійних навичок [62, с. 85]. Педагоги підкреслювали, що проведення таких семінарів дозволяло готувати студентів до майбутньої професійної діяльності вже 3 
перших місяців навчання. Для цього на кожне заняття зі спеціальності призначався черговий студент, який самостійно проводив частину пари. Під час підготовки до такого виду діяльності викладачі звертали увагу на основні положення в навчальному матеріалі, вчили студентів передбачати труднощі, які могли виникнути під час викладання навчального матеріалу та можливі помилки 3 боку інших студентів. Після проведення міні-пари викладач коментував правильність її проведення з методичної точки зору [68].

Семінари-прес-конференції у визначений історичний період проводилися декількома студентами, які розподіляли завдання між іншими студентами своєї групи та формували підгрупи керівників (молоді люди, які будуть проводити семінар), спеціалістів (ставлять запитання) та експертів (оцінюють роботу групи). Така форма семінарських занять дозволяла студентам випробувати себе в усіх вищеназваних підгрупах та набути досвід участі у кожній з них.

Аналіз педагогічної літератури засвідчив, що завдання спецсемінарів науковці досліджуваного періоду розуміли по-різному. Г. Гержод та А. Курас під час проведення спецсемінарів ознайомлювали студентів із завданнями для самостійної роботи, які вони будуть виконувати, зі специфікою майбутньої самостійної роботи, допомагали студентам засвоїти методи узагальнення та аналізу навчального матеріалу, надавали методичну літературу для виконання завдання.

Інший підхід до проведення спецсемінарів висловлювали викладач Київського державного університету Г. Соболєва та співробітник науководослідного інституту проблем вищої школи М.Гарунов. Основною метою спецсемінарів вони вважали поглиблене вивчення окремої навчальної теми та першоджерел. Основною формою підготовки студентів до таких семінарів була їхня самостійна робота, яка дозволяла ознайомитися $з$ методологією науки та вивченням розвитку суспільства. Аналогічну думку висловлювала й викладач Білоруського державного педагогічного університету О. Панько. Під час проведення спецсемінарів педагог також акцентувала увагу студентів на необхідності вивчення наукової літератури, складення бібліографії з теми, що 
опрацьовується, картотеки методики дослідження, забезпечення глибокої підготовки до виступів із доповідями та рецензіями на роботи своїх одногрупників [57, с. 6, с. 16$]$.

Значну роль у становленні студентів як майбутніх спеціалістів та активізації їхньої самостійної роботи відігравали й практичні заняття, практикуми. Як свідчить дослідження, метою практичних занять другої половини XX ст. було відпрацювання умінь та навичок, узагальнення, систематизація та закріплення нової навчальної інформації, набуття практичних умінь, які були необхідними для подальшої професійної діяльності. Педагоги вітчизняних університетів досліджуваного періоду чітко усвідомлювали, що практичні заняття не можуть бути корисними та ефективними без організації самостійної роботи студентів.

Так, деканатом та радою філологічного факультету Харківського державного університету для активізації самостійної роботи студентів на практичних заняттях 3 профільних дисциплін було розроблено конкретні вказівки щодо проведення практичних занять з метою посилення контролю за їх якістю. Як наслідок - студенти стали більш систематично опрацьовувати матеріал, що вивчався, значно підвищився рівень їх знань [64].

У напрямку активізації самостійної роботи під час проведення практичних занять працювали й інші викладачі вищої школи другої половини ХХ ст. (Л. Александров, А. Борбат, К. Латишева, М. Рудіцин, А. Федорченко та ін.), які дійшли висновку, що практичні заняття, під час яких один студент вирішує на дошці завдання, а інші переписують його у свій зошит є мало ефективними. Тому професор А. Федорченко та доцент А. Борбат (Київський державний університет) більшу частину практичних занять проводили у вигляді самостійної роботи студентів.

Схожі ідеї щодо організації практичних занять упроваджувалися і в Одеському національному політехнічному університеті (у минулому політехнічному інституті). Так, на першому вступному практичному занятті 3 фізики студентам видавалися всі задачі, які вони мали розв’язати протягом 
семестру, та список необхідної літератури. На цьому ж занятті розв’язувалися типові задачі під керівництвом викладача. На решті практичних занять студенти самостійно розв’ язували задачі. Для отримання заліку з фізики кожен із них мав самостійно розв’ язати 2-3 задачі біля дошки та показати викладачу зошит зі всіма виконаними завданнями. Причому біля дошки студентам не дозволялося користуватися своїми записами, для отримання інформації щодо розв'язання задачі їм видавалися довідники. Як зазначив викладач фізики В. Лотоцький, така методика проведення практичних занять сприяла розвитку активності та самостійності студентів, підвищенню їхньої рефлексивності у виконанні завдань, виключала можливість несамостійного виконання завдань та стимулювала дострокове отримання заліків. Аналогічний досвід побудови практичних занять накопичено і в інших вищих навчальних закладах [70, с. 18].

У ході дослідження виявлено, що у другій половині XX ст. багато викладачів дійшли висновку, що традиційна методика проведення лабораторних занять мала низку недоліків. Найбільш типовим 3 них був однаковий темп роботи студентів, що значно знижувало їх пізнавальну активність. 3 урахуванням цього $з$ деяких дисциплін педагоги розробляли та впроваджували інші методики проведення лабораторних занять. Так, М.Гарунов в основу організації лабораторних занять поклав ідею про те, що найефективніший розвиток самостійності та творчості проявляється у тому випадку, коли вони максимально наближені до професійної діяльності. Посилення творчої самостійної роботи студентів він досягав насамперед за рахунок проведення лабораторних практикумів на основі дослідження єдиного об’єкта, практикумів-досліджень, які організовувалися безпосередньо на виробництві, а також залучення студентів до участі в технологічних ділових іграх, під час яких ігрові ситуації вимагали здійснення експериментальної роботи з боку студентів [59].

Як з’ясовано, кафедри вищих навчальних закладів весь час систематично працювали над покращенням якості проведення лабораторних занять. Причому особлива увага приділялася прищепленню практичних навичок i вмінь, проведенню самостійних дослідів та експериментів. Перед проведенням 
лабораторних занять викладачі обов'язково перевіряли попередню готовність студентів до виконання лабораторних робіт, що надавало можливість виявити ступінь володіння студентами навчальним матеріалом. Тільки після цього педагоги вирішували, чи можна допустити студентів до виконання лабораторної роботи. Студентам такі попередні співбесіди дозволяли виявити недоліки у своїх знаннях та своєчасно ліквідувати їх.

Дослідження свідчить, що у вищезазначений період студенти після ретельного вивчення методичних вказівок до кожної конкретної лабораторної роботи знайомилися 3 об'єктом дослідження, отримували уміння та відпрацьовували навички роботи 3 технікою, спеціальним обладнанням, приладами та іншою апаратурою, на практиці оволодівали методами досліджень, самостійно виконували лабораторні завдання, вчилися аналізувати отримані результати та робити 3 них логічні висновки. На молодших курсах особлива увага 3 боку викладачів зверталася на формування навичок 3 лабораторної роботи та закріплення їх систематичними вправами на практиці $[64$, c. 19$]$.

Зокрема, викладач Харківського державного університету В. Махінько організовувала виконання лабораторних робіт таким чином, щоб на цих заняттях студенти виявляли ініціативу та творчо підходили до поставленого завдання, вносили свої поправки до тієї чи іншої методики, знаходили нові варіанти рішення завдань. Накопичений педагогами досвід роботи в університеті дозволив їм зробити висновок, що отримані на молодших курсах уміння та навички з кожним роком вдосконалювалися та збагачувалися, що надавало можливість знайомити студентів старших курсів зі складними методами науково-дослідної роботи, які надавали можливість проводити самостійні наукові дослідження [73].

Необхідно підкреслити, що для підвищення самостійної роботи студентів у вітчизняних університетах розроблялися також методичні рекомендації, вказівки, поради, плани семінарських занять, які містили ключові теоретичні 
питання та джерела для самостійного опрацювання, формулювалися поради щодо організації самостійної роботи студентів

Для вдосконалення навичок самостійної роботи студентів вітчизняних університетів велике значення мали й позааудиторні форми навчальної роботи, метою яких було набуття навичок самостійної роботи з літературою, уміння організовувати власну працю, логічно мислити, аналізувати та узагальнювати інформацію.

Як свідчить аналіз архівних документів та наукових праць педагогів другої половини XX ст., особлива увага викладачів під час організації самостійної роботи студентів приділялася навчально-дослідницькій та науководослідницькій роботі, які реалізовувалися під час написання рефератів, курсових, дипломних робіт, під час участі студентів у наукових студентських гуртках, товариствах, семінарах, конференціях, конкурсах на кращі студентські роботи, підготовки публікацій тощо.

У другій половині XX ст. навчально-дослідницька робота студентів розглядалася як складова навчального процесу, яка реалізовувалася як у процесі проведення аудиторних занять, так і у позааудиторній роботі. До основних завдань навчально-дослідницької роботи студентів проректор Тернопільського національного педагогічного університету (у минулому державний педагогічний інститут) М. Кас'яненко відносив такі: оволодіння студентами сучасними прийомами та методами досліджень, формування у них методів та засобів творчої діяльності, набуття молодими людьми відповідних навичок та вмінь 3 дисципліни, що вивчається [64, с. 21].

Науково-дослідницька робота студентів була органічним продовженням навчально-пошукової діяльності студентів та спрямовувалася на ознайомлення 3 науковою літературою, технікою та методикою проведення експериментів, тогочасними методами наукового пізнання, на поступове збільшення самостійності у виконанні дослідницьких робіт. Як правило, науководослідницька робота студентів здійснювалася на засіданнях наукових гуртків, в лабораторіях, на наукових семінарах та конференціях та виконувалася під 
керівництвом викладача. У цьому плані важливим $є$ зауваження професора Одеського державного університету О. Розанова стосовно того, що студентів необхідно привчати не тільки до самостійного проведення експериментів, ретельного фіксування результатів своїх досліджень, але й до підтримання порядку на робочому місці. Педагог зазначав, що це важливо не тільки 3 естетичної точки зору, але й впливає і на якість експериментів, що проводяться $[75]$.

Відзначимо, що значну роль в організації самостійної роботи студентів відігравали і студентські конференції, які дозволяли встановити зв’язок курсу, що вивчається, зі спеціальними дисциплінами та досягненнями науки, поглибити знання. Аналіз педагогічної літератури засвідчив, що студентські наукові конференції проводилися у багатьох вітчизняних університетах. Так, в Київському державному університеті імені Т. Шевченка: у 1958 р. 3 доповідями на студентській конференції виступили 245 осіб із 1000 членів наукового товариства, тоді як у 1959 р. у такій конференції взяли участь вже 347 студентів iз 2000. Разом 3 тим, П. Кононенко (Київський державний університет) акцентував увагу на зміні не тільки кількісного показника, але й якісного: науковою роботою займалися ті студенти, які дійсно прагнули здійснювати науковий пошук [76].

Як правило, студентські конференції у другій половині ХХ ст. охоплювали діяльність декількох груп або цілого потоку. Усна доповідь складала 7-10 хвилин, причому під час доповіді студенти мали формулювати ідеї своїми словами, користуючись тільки наочним матеріалом, а не читати з листка.

Досвід організації конференцій 3 іноземної мови було описано й Л. Болговою та В. Яровою. Педагоги зазначали, що для підвищення мотивації щодо самостійної підготовки до конференції ними було оголошено, що найкращі доповіді будуть відзначені й нагороджені журі. У зв’язку з високим рівнем підготовки до конференції цей захід викликав значний інтерес як у студентів, що виступали з доповідями, так і у слухачів. Після кожної доповіді проводилося обговорення англійською мовою [68]. 
У ході наукового пошуку встановлено, що правильно організована навчально-дослідницька та науково-дослідницька діяльність забезпечувала здатність до самостійної творчої роботи, формування навичок грамотного проведення експериментів та аналізу їх результатів.

Підсумовуючи, необхідно зазначити, що вивчення педагогічної спадщини вищої школи другої половини ХХ століття дозволяє переосмислити підходи до організації самостійної роботи студентів університетів та творчо використовувати здобутки педагогів у сучасному процесі навчання. 